\title{
Transcending Normative Labels in Diasporic Women's Literature: From Stable Identities to Limbo Subjectivities
}

\section{Myriam Moïse}

\section{(2) OpenEdition Journals}

Electronic version

URL: https://journals.openedition.org/ces/5273

DOI: $10.4000 /$ ces.5273

ISSN: 2534-6695

\section{Publisher}

SEPC (Société d'études des pays du Commonwealth)

\section{Printed version}

Date of publication: 1 September 2013

Number of pages: 33-43

ISSN: 2270-0633

\section{Electronic reference}

Myriam Moïse, "Transcending Normative Labels in Diasporic Women's Literature: From Stable Identities to Limbo Subjectivities", Commonwealth Essays and Studies [Online], 36.1 | 2013, Online since 16 April 2021, connection on 22 July 2021. URL: http://journals.openedition.org/ces/5273 ; DOI: https://doi.org/10.4000/ces.5273

\section{(c)}

Commonwealth Essays and Studies is licensed under a Licence Creative Commons Attribution - Pas d'Utilisation Commerciale - Pas de Modification 4.0 International. 


\section{Transcending Normative Labels in Diasporic Women's Literature: From Stable Identities to Limbo Subjectivities}

This article examines the shifting nature of self-identification through the analysis of the short fiction of Nalo Hopkinson and M. NourbeSe Philip. These writers stretch the identification process beyond canonical borders and appear to unsettle identity labels. Choosing unsteadiness and uncertainty over stability and fixity, they turn any normative labelling upside down, thus promulgating their limbo subjectivities beyond the geographical, conceptual and ideological limits imposed by hegemonic frameworks.

Hegemonic normative frameworks tend to envision identity as a fixed and static selfconstruction which is intrinsically linked to rigid canonical labels. As regards narratives of the self, these may prioritize "self-constancy" as French philosopher Paul Ricoeur puts it, or they may take the form of "stability narratives," (249) which promote "the common desire for the social world to appear orderly and predictable" (Gergen and Gergen 267). However, when referring to subjectivity and identity, one must consider the fact that subjecthood does not automatically entail the grounding of a stable identity. Stuart Hall's concept of identification is pertinent as it describes a progressive process rather than a static self-positioning. Hall sees identification as "a process of articulation, a suturing, an over-determination not a subsumption. There is always 'too much' or 'too little' - an over-determination or a lack, but never a proper fit, a totality" (3). Despite the current age of mass migration and mass mediation, examining identity in the literatures that fall outside hegemonic cultures (i.e. European and American) appears problematic. The heterogeneous and unstable nature of a diaspora often implies the instability of national identity and the disruption of a homeland. In this sense, an exploration of the creative writings by African-Caribbean women living in North America entails taking into account the "relational positionality" of the diasporic subject, a term coined by Susan Friedman:

Within a relational framework, identities shift with a changing context, dependent always upon the point of reference. Not essences or absolutes, identities are fluid sites that can be understood differently depending on the vantage point of their formation and function. (47)

The diasporic experience is indeed one of instability and fluidity as it represents a constant journey, whether physical or imagined, between two cultural spaces. As Stuart Hall puts it, "the subject assumes different identities at different times, identities which are not unified around a coherent 'self.' Within us are contradictory identities, pulling in different directions, so that our identifications are continually being shifted about" (27).

Diasporic Caribbean writers are often considered to be "out-of-country" and "outof-language," as Salman Rushdie puts it in Imaginary Homelands (12). The present paper seeks to emphasise the possibility for the subject to develop several identities, hence to exist beyond normative labels. It proposes an examination of subjectivity as a fluid process that escapes rigorous labelling; it aims at demonstrating the extent to which Jamaican-Canadian author Nalo Hopkinson and Trinidadian-Canadian writer M. NourbeSe Philip portray diasporic selves as situated out-of-identity. Hopkinson's work fits this 
analysis of diasporic voices because it stretches the boundaries of the science fiction genre and often represents Caribbean women striving to survive or voice their individualities in a global world. Her transformation of science fiction into a transcultural genre is comparable with M. NourbeSe Philip's manipulation of discourse, as the latter often blurs the boundaries between prose and poetry, and between the oral and the written. In their short stories, respectively "Slow Cold Chick" and "Burn Sugar," Hopkinson and Philip re-imagine the self as plural and unstable and depict subjectivities as constantly renegotiated and able to fuse in order to shape new selves.

According to Chris Barker, subjectivity is "the condition of being a person; that is how we are constituted as cultural subjects and how we experience ourselves" (219). This analysis will therefore consider subjectivity and identity as "contingent, culturally specific productions" and identity "not as a fixed entity but as an emotionally charged discursive description of ourselves that is subject to change" (Barker 220-1). It is the very fluid nature of identities that this analysis seeks to bring to the fore; that is, the way these authors' discursive strategies express their inner and outer utterances beyond static spaces and normative language, and construct what I call their limbo subjectivities. The in-betweenness and the state of unbalanced existence expressed in these authors' narratives indeed recall the limbo, that "bordering place," neither here nor there, "a state of nonresolution or uncertainty" (Hirsch 98). The word "limbo" comes from the Latin "limbus" which means "on the border," or "in-between," "a kind of no-man's land between heaven and hell where the blessed who died before the coming of Christ resided" (Marthaler 172). Limbo also refers to a dance in the Anglophone Caribbean during social events and more particularly during Carnival, but its origin goes back to the Middle Passage. As Wilson Harris explains:

the limbo dancer moves under a bar which is gradually lowered until a mere slit of space, it seems, remains through which with spreadeagled limbs he passes like a spider. Limbo was born, it is said, on the slave ships of the Middle Passage. There was so little space that the slaves contorted themselves into human spiders. (156)

Through an emphasis on the relationship between self and language, the analysis of a sample of the short fiction of Philip and Hopkinson will prove that the production of speech does not necessarily depend on how people are labelled, but rather how they identify themselves. The two authors may indeed choose unsteadiness to reconstruct their identities, thereby positioning themselves within a staggering and fluid process of self-identification. They enhance the complexities of their diasporic female subjectivities and envision self-transformation through their short stories, which appear to move beyond hegemonic rules. They constantly try to transcend normative boundaries, hence illustrating the transformability and changeability of identities, spaces and discourses.

The comparative analysis of their discursive strategies must be considered with regard to linguistic layers: Creole, Standard English and Caribbean Demotic. Besides, these two short stories have been selected for their common reference to the recipe genre, as Hopkinson and Philip appear to transform a baking project into an identity-making enterprise. It is clear that "recipes follow strict rules [and] belong to a very rigidly defined cultural genre" (Rosello 107). However, Hopkinson and Philip appear to transform the recipe genre and shift it from given instructions to unexpected occurrences. Multiplying meanings and transcending rigorous labels, they deny the definition of the recipe as an "intrinsically written genre" (Warnes 53) and choose to foreground 
its orality. Their discursive strategies are reminiscent of "the simulation of speech" and "the allusions to recipes exchanged using precisely the vernacular channels" (Warnes 54) that characterise the African-American cookbook tradition. Kitchen talk has become a valued tradition in contemporary writings by women in Canada and in the USA. Barbadian-American author Paule Marshall was among the first diasporic Caribbean women to depict the kitchen as a liberating space and a feminine space of discursive agency ("From the Poets in the Kitchen"). A number of writers further associate the kitchen with trans-generational cultural transfer: the ritual of the recipe is often depicted as passed on and reinvested, thus strengthening the mother-daughter bond. ${ }^{1}$

Nalo Hopkinson's short story "Slow Cold Chick," which was published in her collection of fantasy science fiction Skin Folk, opens on the protagonist's concern with making cornbread according to her mother's recipe. In the middle of her baking attempt, Blaise is confronted with the absence of a recipe as well as with the impossibility of reaching her mother on the phone. This absence of oral guidelines foreshadows the lack of rigour of her baking enterprise yet to come.

They'd cut off the phone. Blaise slammed the receiver back into the cradle. "Oonuh couldn't wait just a little more?" she asked resentfully of the silent instrument. "I get paid Friday, you know." Now she couldn't ask her mother to put milk or water in the cornbread. Chuh. (103)

The attempt at reproducing orality is immediately featured, not only through the onomatopoeia "Chuh," but also through the direct speech of the Caribbean demotic which appears through the ellipsis of pronouns and the minimalist syntax of Blaise's speech. As opposed to a traditional recipe, where one follows given instructions, Blaise has to use her memory to recall "her mother's home-made cornbread, yellow-warm smelling, hot from the oven, with butter melting more yellow into it. Yes, Mummy used milk" (103). The use of free indirect speech allows the reader to hear the protagonist's spoken words and enter her mind. Cornbread is staple food in the Americas and a recurrent item in narratives dealing with poverty. Blaise's precarious and unstable situation is conveyed through her double quest: her search for the few ingredients she needs to bake cornbread and her quest for her mother's recipe.

M. NourbeSe Philip's story "Burn Sugar" also starts with the protagonist referring to her mother's recipe, but it deals with a classic Caribbean dish: the black cake. Where Hopkinson's narrative refers to the recipe as the starting point, Philip's short story develops a rather different strategy as she places the recipe at the very heart of her narrative. The language of the story oscillates between Standard English and the Caribbean demotic, and between the oral and the written. Its lack of grammatical rigour contrasts with normative conceptions of cook books. Readers who are not used to the Caribbean demotic may need a second reading to understand that "Burn Sugar" is a genuine narrative of development. It tells the story of a young Caribbean woman who has migrated to a North American city, presumably New York, and who, for the first time, does not receive the black cake sent every year by her mother from the Caribbean:

1. While the space of the kitchen as a space of agency is a recurrent motif in Caribbean women's fiction, a number of works by Caribbean male writers also depict the mother's ritual in the kitchen in terms of empowerment. For instance, in George Lamming's novel In the Castle of my Skin, the episode in which G.'s mother prepares his last meal before his departure is central in asserting the mother's cultural power and the importance of identity construction. The detailed account of the mother's recipe of the Barbadian specialty flying fish and cuckoo interrupts the narrative and enhances the importance of the kitchen scene as reinforcing the unalterable bond between mother and son. 
It don't come, never arrive, had not - for the first time since she leave, had left home; is the first time, for the first time in forty years the Mother not standing, had not stood over the aluminium bucket with her heavy belly whipping up the yellow eggs them and the green green lime skin. "People does buy cake in New York," she say, the Mother had said, "not make them." (405)

The story therefore starts with a feeling of loss and lack as the protagonist misses the cake and must bake it herself, and this confusion is conveyed to the reader through the agrammatical and hesitant expression displayed in the extract. The duplication of the verbal structures ("she leave, had left home," "not standing, had not stood") not only puts emphasis on an exceptional event occurring for the very first time, but also on the atemporal nature of this occurrence through the scrambling of tenses, i.e. pluperfect, continuous present, and simple present. The protagonist loses her grounding because of the absence of the cake, and this forces her to remember her mother's recipe and put it into practice for the first time ever. While the mother's speech is absent in Hopkinson's "Slow Cold Chick," it is infused into Philip's story from the beginning, hence announcing heteroglossia throughout. ${ }^{2}$ In Philip's narrative, the discursive presence of the mother is imposed through the recurrent imagery of her "heavy belly," which also recalls the insistence on the physical appearance of Blaise and the Venus-built lady in Hopkinson's short story.

In "Slow Cold Chick," while looking through her kitchen window, Blaise soon seems hypnotized by the beautiful lady "laying a circle of conch shells around a bed of bleeding hearts" (104). From the phone's silence at the beginning of the narrative, the protagonist's mind moves to music, as she imagines "the shells singing as the wind blew past her lips" (105); the mysterious presence of the Venus-shaped lady suddenly brings a different atmosphere to the narrative:

Chocolate-dark limbs peeking out of her plush white dressing gown, the Venus-built lady waded indolently through rioting ivy, swollen red roses, nasturtiums that pursed into succulent lips. [...] As ever, the Venus-built lady's gingered brown hair flung itself in crinkled dreadknots down her back, tangled as lovers' fingers. Blaise had chemically straightened all the kinks out of her hair. (104)

The eruption of the Venus-built lady into the scene is important; as she is situated outside in the garden, it is implied that Blaise actually analyses her inner self while observing her since the narrator constantly refers to Blaise's character. Just after pointing at the mysterious lady's "crinkled dreadknots down her back," a sentence denoting Blaise's relaxed hair is abruptly juxtaposed and underlines Blaise's alienated attempt at suppressing her kinky hair. Similarly, the contrast between the dullness of Blaise's hands and the lady's skin which "had the glow of full-fat chocolate," implies an opposition between the lady's self-confidence and Blaise's quest for her true self (104). Beyond its arguably erotic dimension, this passage announces the protagonist's quest for identity.

From the very beginning of the story, the narrative technique draws the reader's attention to Blaise's unstable identity and her possible need to identify with the Venus-built lady. The latter is immediately depicted as a hybrid character combining aspects of the Hottentot Venus and the Vénus de Milo. Her brown skin and her "crinkled

2. Heteroglossia was Russian theorist Mikhail Bakhtin's term to define “another's speech in another's language, serving to express authorial intentions but in a refracted way. Such speech constitutes a special type of double-voiced discourse" (Bakhtin 324). 
dreadknots down her back" are not only reminiscent of Tan-Tan's "long black knotty locks" in Nalo Hopkinson's novel Midnight Robber (1), they also recall Sarah Baartman, the African woman who was exhibited in nineteenth-century Europe under the name of the Hottentot Venus. On the other hand, the imagery of the "lovers' fingers," the roses, the hearts, as well as the apples, recalls the most ancient Greek statue, the V'́nus de Milo, also called the Aphrodite of Milos. ${ }^{3}$ This statue symbolises an ideal of beauty but also represents love, as Aphrodite was the goddess of love in Ancient Greece. In Hopkinson's short story, the Venus-built lady is the allegory of hybrid identity, as it allows the original elements of the European statue to appear while a number of elements are hybridized. For example, the description of the Venus-built lady does not mention random roses and apples; these are transformed into nasturtiums, the tropical American plants, and otaheite apples, the Caribbean water apples:

Branches laden, an otaheite tree bobbed tumescent maroon fruit, so low that the lady could have plucked them with her mouth. Blaise's mother sometimes sent her otaheite apples from Jamaica, but how did the tropical tree flourish in this northern climate? (104)

The reproduction of the nasturtiums and the resilience of the otaheite apples echoed in the word "maroon" are symbols of the Venus-built lady's diasporic strength. Further in the narrative, while she explains that the otaheite tree "feeds her soul" and "is a flavour of home," Blaise can "taste the warm rose spice of her breath" and notices that "even her skin had the scent of the roses she ate" (112). If her identification by the name of Sharon eventually confirms her human nature, the earlier description of Blaise's special neighbour resembles the depiction of a museum statue and her delayed naming may denote how normative language is unfit to ascribe identity. Through the emblem of her hybrid identity, Sharon remains a central character throughout the story, one who constantly reminds Blaise of the need to live in limbo, neither statue nor human, neither here nor at home, neither spiritual nor physical. The quest for a recipe hence leads to a quest for identity, or more precisely a search for the ingredients initiating one's identity construction.

As Blaise looks for ingredients in the fridge, she avoids the rotting pepper sauce that she throws into the sink while "kiss(ing) her teeth in disgust" (105). She then notices "an egg huddling in one of the little cups inside the fridge door. Where had that come from? Exactly what she needed" (105). Before using it for her recipe, Blaise briefly questions the egg's surprising provenance:

The egg was a little too big for its cradle, a little rounder than eggs usually were. Blaise picked it up. Its cold, mercurial weight shifted in her palm, sucking warmth from her hand. She cracked it into the bowl. With a hollow clomp! a mass disappeared below the surface of the liquid. A sulphur-rot stench filled the kitchen. "Backside!" Blaise swallowed a wave of anger. A bubble of foetid air popped from the depths of the bowl. Blaise grimaced and began to pour the swampy goop down the drain. The tainted milk and oil mingled with the pepper sauce. (105-6)

While the event of a chicken coming from an egg is considered a normal occurrence, the unusual shape of the egg and its abnormal impact on Blaise announce its alien nature. The presence of science fictional elements is marked through the narrator's vocabulary

3. The Aphrodite of Milos was discovered on the island of Milos (also Melos, or Milo) in the Aegean, which was then a part of the Ottoman Empire. The statue was found in two large pieces, the torso and the draped legs, along with pieces of the left arm and the left hand holding an apple. 
which hyperbolizes the description and turns its accepted commonality into something extraordinary: "sulphur-rot stench," "a bubble of foetid air," "mercurial weight." The story therefore appears to shift from normality to oddity and the reader's attention is moved from the cornbread recipe to the broken egg letting its content out. The focus on fluidity further denotes this shift as the first ingredients used for the recipe, milk and oil, mix with the pepper sauce and the egg. At the sight of the cold-grown chick, Blaise feels like vomiting, so that the passage juxtaposes these fluids being thrown away and circulating down the drain with Blaise's bodily fluids which would be thrown up.

Through the emergence of a new identity, this episode is climactic and the birth foreshadows the conflicting atmosphere yet to come. The circulation of liquids can be associated with the circulation of air (breath, smells), as well as with the circulation of sounds in the story, as everything appears amplified. Blaise's conflict with the newborn creature is enacted through the series of onomatopoeias which translate the strange, glossolalic dialogue which occurs between them. "'Urrrr... rattled the coldgrown chick,' 'Shh, shh.' She wadded a tea towel in her free hand and deposited the bird into it. 'Arr...' the chick complained" (106). Trying to get rid of the chick, Blaise eventually addresses it directly and more clearly: "Make up your mind," she flared. "You want fire in your eyes, or cool water?" The chick tried to peck. Blaise hissed angrily, "Well, here, then, take that!" (106-7) Using sarcasm to defy the animal, Blaise warns it and eventually throws the pepper sauce at it, hoping to burn its eyes. However, the slow cold chick does not have the expected reactions as instead of hurting it, the spicy liquid appears to double its strength:

The chick swallowed, withdrew its pinny head into its ugly neck, and closed its eyes.

"That do you for now?" Blaise asked it.

The chick purred, a low, rattling sound. It radiated heat into her hand. It wasn't so ugly, really. She tucked its warmth close to her breast. (107)

The spoiled pepper sauce serves as a feeding ingredient for the chick which actually turns warm. Blaise's position therefore appears to vacillate between that of the hunter and the feeder. The sounds produced by the chick also seem to be unstable as they shift between wailing, shrieking (106) and then purring with pleasure as the animal comes closer to Blaise. The orality of the story reaches its climax as sounds and glossolalic voices multiply and intensify throughout the identity process: from the chick who "hissed a sound like steam escaping," (108) to its "wet crunching sound" when he devours the ferret (109). It seems that Hopkinson's magical story allows the reader to hear every single sound, as though she believed, like Kenneth Burke, in an "entelechial" interpretation of language, according to which even the simplest infantile sounds would have in them the possibilities of linguistic fulfilment" (Language as Symbolic Action 427). As a matter of fact, Hopkinson truly incites her reader to consider speech "beyond the traditional bounds of rhetorics" as "there is an intermediate area of expression that is not wholly deliberate, yet not wholly unconscious. It lies between aimless utterance and speech directly purposive" (Burke, Rhetoric of Motives xiv). The intermingling of sounds, solids and fluids in expressions such as the "wet crunching sound" followed by Blaise hearing "her own panicked sobbing" demonstrates that beyond the apparent chaos, new voices and new identities may emerge. The cornbread recipe started with the same association of fluids, solids and sounds, but it turned into an experience of the uncanny 
for Blaise, thus demonstrating the extent to which subjectivities can be shifted and unexpectedly transformed.

Blaise's experience indeed illustrates the performance of fluid subjectivities: the chick does not attack her but continues its transformation, and develops a new identity when it metamorphoses into a cockatrice. As the story started with Blaise cracking an egg for her cornbread recipe, the presence of the cockatrice figure appears as a biblical symbol: 'They hatch cockatrice's eggs, and weave the spider's web: he that eateth of their eggs dieth, and that which is crushed breaketh out into a viper" (Isaiah 59.5). The growth of the cold chick into a cockatrice immediately leads the reader to interpret the story with regards to motifs of self-image and self-identification. The coming of the cockatrice is indeed associated with a false identity, namely, "the false self, which is a distortion of the truth of man, hatches the eggs of the cockatrice":

They trust in the vanity of the false counterfeit self which they believe they are, and they speak lies based upon the human self, that they believe they are, instead of the spirit in human form which they really are; they conceive mischief when functioning from this false identity, and this error in identity brings iniquity and evil in many forms. [...] The cockatrice is a mythical serpent that hatches from an egg and is deadly to anyone who feels its breath on them or sees its glance. (Monaco 249)

Throughout the story, the imagery of the cockatrice recurs as numerous references are made to the chick's glance having a direct impact on Blaise; for instance, when "its reddened eyes glared accusingly at Blaise," when "it sat up straight in her palm, staring alertly at her," or when "it stared at her with a fierce intelligence" $(106,107,108)$. Blaise is therefore the epitome of the false self which is the target of the cockatrice, but instead of a deadly glance, the story allows self-awareness and transformation. Hopkinson thus deconstructs the biblical master narrative and manipulates the image of the cockatrice as the latter does not provoke death but rather transformation and the fusion of identities.

At the end of the narrative, the presence of the cockatrice takes on all its significance; it leads to an unexpected outcome as Blaise is forced to accept the change occurring within herself and to voice her truth. As she manages to express herself, and as she asserts her genuine identity, Blaise's transformation, revealed through stylistic and linguistic shifts, further affects the cockatrice. Self-expression and self-truth are indeed the keys to preventing the cockatrice from killing and burning human beings: "Blaise took a step towards the cockatrice. Birdlike, it cocked its head. It mewed a question. 'I want,' she said, her voice quaking out the unfamiliar word, 'to be able to talk what I feel"' (116). As Blaise liberates her speech, the cockatrice which was "hot, hot" and "burning with heat," "leapt into her arms":

Impossibly, it crammed its whole head into her mouth. Blaise gagged. She could feel its beak sliding down her throat. [...] With a great heave, its whole bulk slid into her stomach. She could feel its muscly writhing, its fire that now came from her core. She could breathe, and she was angry enough to spit fire. (116-7)

Whereas the chick had swallowed the ferret during an earlier scene, the cockatrice now forces herself into Blaise's body, so that the latter has to swallow the beast. In a sense, she not only swallows the cockatrice but the multiple identities the latter represents, from the chick to the ferret. Blaise's body therefore becomes a locus of hybridity as she has transmuted and her identity now encompasses the natural and the supernatural, 
the human and the animal, the real and the magical. Fire, which is a recurrent motif throughout the story through the heat generated by the beast, is now fully transferred onto Blaise and besides, her name suggests that she was originally connected with fire. The name "Blaise" means fire (homonym blaze), and Saint Blasius (fourth century) supposedly possessed miraculous healing powers. Blaise is indeed forced to assert her fiery identity and her magical powers are announced at the close of the story as she feels "strong, sure of herself" (117).

The limbo manifests itself during the transitional period that Blaise experiences when she is split between her false self and her true self and it is the cockatrice who pushes her to formulate her genuine self and actualize her limbo subjectivity. This unstable state is reminiscent of what Dominique Aurelia calls "the poetics of staggering," the "interstice" which is "never safe, never stable, but unpredictable and disrupted":

it is therefore a complex place of life and death, of permanent recreation and re-invention of the self that tries to determinate itself through the interweaving of the ambiguities of accommodation, as in state of limbo governed by uncertainty and dis-membering. (81)

Blaise is at the crossroads of identities, and it is only through speech, through her own utterance, that she manages to acknowledge her liminal identity. Going from the cornbread recipe to the birth of the cockatrice, the story allows, as the author herself puts it, "the irrational, the inexplicable and the mysterious [to] exist side by side each with the daily events of life" (Whispers xi). Hopkinson mixes European mythology and Caribbean folklore; hence her stories cannot be categorised and her characters' identities are often staggering and always in tension in the whole Skin Folk collection. In her introduction to Skin Folk she writes:

Throughout the Caribbean, under different names, you'll find stories about people who aren't what they seem. Skin gives these skin folk their human shape. When the skin comes off, their true selves emerge. They may be owls. They may be vampiric balls of fire. And always, whatever the burden their skins bear, once they remove them - once they get under their own skins - they can fly. It seemed an apt metaphor to use for these stories collectively. (1)

Hopkinson's multi-shaped creature represents the fluid identities, which merge with each other and are constantly renegotiated, and the absence of a rigorous recipe implies the need to escape genre categorisation, as well as the absolute need to transcend given instructions. From the random baking activity a new self has emerged, and even though Blaise has not had access to her mother's recipe, she has managed to express her own speech and concoct her own recipe with unlabelled ingredients.

Baking a Caribbean dish in North America is certainly one of the most common enterprises for the diasporic subject and, as Derek Walcott puts it:

The further we move from home, the more strongly rooted the particular becomes, the more distinctive and describable those things that are true to their time and place, whether they are the indigenous components of a novel, a play or a recipe. (3)

A number of Caribbean women writers have underlined the need to master those home recipes. In a poem by Trinidadian-Canadian writer Claire Harris, Drawing Down a Daughter, the motherly voice draws up a list of the local dishes to be absolutely mastered by a Caribbean girl and announces "the gospel on bakes" (44). This phrase implies a sacred dimension that echoes Philip's story in which the protagonist remembers "watching, observing the Mother's rituals" (406). In "Burn Sugar," the mother is a significant cha- 
racter as the word "mother" is always written with a capital "M," as though it were a first name, thus denoting the importance of the mother figure throughout the narrative. A sacred status is attributed to the Mother through her production of sound during the baking process; "the Mother's sound" is a metaphor of the language which is shared between mother and daughter in the kitchen. The protagonist recalls the noises produced during the making of the cake batter and despite their apparent commonality, these sounds are meaningful to her:

She want it to be all over now - quick, quick, all this mixing and beating and mixing, but she notice the sound change now that the eggs meet the butter - it heavier and thicker, reminding her it reminds her of the Mother - she and the Mother together sharing in the Mother's sound. She leans leaning over the bucket watching how the eggs and butter never want to mix, each resisting the other and bucking up against the Mother force. $(408-9)$

Contrasting with the opening paragraph, as Philip's protagonist remembers her mother's gestures, position and sounds while baking, the language here is slightly more comprehensible. However, the discursive stumbling, through the verbal duplication, is still present ("she leans, leaning") and is intensified by a play on adjectives and comparatives ("quick, quick," "heavier and thicker"). The assonance in [r] ("over," "butter," "together") and the pattern of repetition of adjectives, add some musicality to the prose, hence the language stutters throughout the narrative.

Reading Philip's short story in detail would probably allow one to follow each stage of the black cake recipe, but it seems that what is actually developed is an identity recipe, as though the burn sugar ${ }^{4}$ were a metaphor of self-construction. Throughout the story, the Mother is depicted as mastering the recipe instructions and technique, and as possessing the secrets for making the "magic liquid," the burn sugar:

The sugar never change when she expect it to, not once in all the years she watching, observing the Mother's rituals. Too quick, too slow, too late - it always catch she - by surprise - first the sugar turn sticky and brown at the edges, then a darker brown - by surprise - smoke stinging, stings her eyes, tears run running down she face, the smell sharp and strong of burning sugar - by surprise - she don't budge, she stand still watching, watches what happening in the pot - by surprise. (406)

The bittersweet burn sugar, which is the most important ingredient, becomes the epitome of transformation and identity formation. The fact that it is a process is underlined by the use of the gerund but it is an unstable process, one where anything can happen "by surprise." The narrator's recurrent interjection of the latter phrase enhances the un-expectability of the enterprise and the recipe is taken out of its normative regularity. Instead of remembering an accurate recipe for the cake, the protagonist is confronted with the uncanniness of the magic liquid:

She look down at the liquid - she use to call it she magic liquid; is like it have a life of it own - it own life - and the cake need it to make it taste different. She glance over at the Mother - maybe like she need the Mother to taste different. She wonder if the Mother need her like she need the Mother - which of them was essential to the other - which of them was the burn sugar? (407)

4. In the Dictionary of the English/Creole of Trinidad and Tobago, "burn sugar" is a phrasal verb defined as "start to brown down meat by melting and caramelizing sugar in hot oil to darken the meat and its gravy" (141). 
Comparing her Mother-daughter relationship with the link between the cake and the burn sugar, she allegorizes her life. The more she questions her own identity with regard to her mother's, the more elaborate the language seems:

It was its failure to arrive - the absence of the cake - even with its "funny" smell that drove her to this understanding, this moment of epiphany as she now stood over her cheap, plastic bowl and watched the spoon. She looked down at her belly, flat and trim where the Mother's easily helped balance the aluminium bucket - not like, not like, not like her - she hadn't wanted to be like her, but she was trying to make the mother's black cake, all those buckets of batter she had witnessed being driven through their changes were now here before her - challenging her. (409)

As she remembers her mother preparing the black cake recipe, the protagonist comes to a realization of her difference: "she was different - from the Mother - as different perhaps as the burn sugar was from the granulated sugar, but of the same source" (410). The narrator emphasises her difference through the triplication "not like, not like, not like her," but she also underlines their reunion through the making of the black cake. The comparison with the burn sugar signals the impossibility of coming back to the initial state and the strength of the transformation process. For the young female protagonist, the cake becomes the embodiment of the limbo self as it embraces fluidity and solidity, sweetness and bitterness, past and present. The protagonist is different from her mother despite their similar roots, and this difference/sameness pattern is confirmed in her eventual baking of the cake at the close of the story. Although she tries to perform the Mother's rituals and mimic her sounds, her cakes do not look the same:

The insides were moist and tasted like they should - the bitter, sweet taste perfectly balanced by the deep, rich, black colour. But the crust had ruined them. [...] It was the Mother's advice that saved them. Following her instructions by phone, she cut all the crusts off the cakes, then poured rum over them to keep them moist. She had smaller cakes now - not particularly attractive ones either, but they tasted like black cake should, and without that funny smell. (411)

In a sense, cutting the edges allows the reshaping as well as the border-transcending and adding rum denotes the importance of fluidity. Through an inside/outside dialectic, this final image further enhances the cake as a symbol of the fluid and transcultural diasporic identities which are constantly renegotiated. The fact that the protagonist actually bakes several cakes rather than a single one also symbolizes multiple subjectivities and confirms the metamorphosis which was previously announced.

In "Burn Sugar" as in "Slow Cold Chick," unexpected subjectivities are created and the baking experience goes beyond the motherly instructions, turning into an eclectic experience where language, space and selves are interwoven. At the close of both narratives, the limbo fully expresses itself: through Philip's failed black cakes which are then reshaped; through Hopkinson's alien being which fuses with the protagonist, and gives birth to a hybrid self who staggers between the human and the animal, between the normative and the magical. Whereas Hopkinson chose science fiction to allow Blaise to undergo metamorphosis via the cockatrice, Philip's narrative allows transformation through the recreation of the black cakes. The self is therefore re-imagined as plural and unstable and subjectivities are never static, but constantly renegotiated in order to shape new selves. Both authors seem to envisage self-transformation and renewal within a staggering process which cannot possibly be labelled. The feminine limbo subjectivities exist within liminal spaces and the diasporic voices are plural. Philip and 
Hopkinson allow dissonant rhetorics to emerge; they transcend given instructions and imagine new processes of identity constructions beyond normative labels. They truly recompose the recipe genre and inscribe their narratives within the tradition of kitchen stories, demonstrating (as Edna Alford and Claire Harris have put it in their collection of Canadian women's prose and poetry entitled Kitchen Talk), that "the kitchen is a power-site where all the senses are called into action. [...] It's a place of transformations and creativity" (14).

Myriam MOÏse

University Paris 3-Sorbonne Nouvelle University of the West Indies, St Augustine

\section{Works Cited}

Alford, Edna, and Claire Harris, eds. Kitchen Talk: Contemporary Women's Prose and Poetry. Alberta: Red Deer College P, 1992.

Aurelia, Dominique. "In Search of a Third Space: Fabienne Kanor's Humus.” Small Axe 36 (November 2011): 80-8.

BAKHTIN, Mikhail. The Dialogic Imagination. Ed. Michael Holquist. Trans. Caryl Emerson and Michael Holquist. Austin: U of Texas P, 1981.

BARKER, Chris. Cultural Studies: Theory and Practice. London: Sage, 2011.

BurKe, Kenneth. Language as Symbolic Action: Essays on Life, Literature and Method. Berkeley: U of California P, 1966.

—. A Rhetoric of Motives. Berkeley: U of California P, 1969.

Friedman, Susan Standford. Mappings: Feminism and the Cultural Geographies of Encounter. Princeton: Princeton UP, 1998.

Gergen, Kenneth, and Mary M. Gergen. "Narratives of the Self." Studies in Social Identity (1983): $254-73$.

HaLL, Stuart. Questions of Cultural Identity. Ed. Stuart Hall, and Paul Du Gay. London: Sage, 1996.

Harris, Claire. Drawing Down a Daughter. Fredericton, NB: Goose Lane, 1992.

HARris, Wilson. History, Fable and Myth. Wellesley: Calaloux, 1983.

Hirsh, Eric Donald. The New Dictionary of Cultural Literacy: What Every American Needs to Know. New York: Houghton Miffling, 2002.

Hopkinson, Nalo. "Slow Cold Chick." Skin Folk. New York: Warner, 2001. 103-17.

-. Whispers from the Cotton Tree Root: Caribbean Fabulist Fiction. Montpelier, VT: Invisible Cities, 2000.

—. Midnight Robber. New York: Warner, 2000.

Lamming, George. In the Castle of my Skin. 1953. Ann Arbor: U of Michigan P, 1991.

Marshall, Paule. "From the Poets in the Kitchen." Reena and Other Stories. New York: The Feminist P, 1983. 3-12.

MarTHALer, Berard. The Creed: The Apostolic Faith in Contemporary Theology. London: Bayard, 2007.

Monaco, Anthony John. The Testimony of the Major Prophets. Bloomington: AuthorHouse, 2004.

Philip, M. NourbeSe. "Burn Sugar." The Oxford Book of Stories by Canadian Women in English. Ed. Rosemary Sullivan. Toronto: Oxford UP, 1999. 405-11.

Ricoeur, Paul. Time and Narrative III. Trans. Kathleen McLaughlin and David Pellauer. Chicago: U of Chicago P, 1987.

Rosello, Mireille. Infiltrating Culture: Power and Identity in Contemporary Women's Writing. Manchester: Manchester UP, 1996.

RusHDie, Salman. Imaginary Homelands: Essays and Criticism 1981-1991. London: Granta, 1991.

The King James Bible. 1611. New York: Pure Cambridge, 1995.

WALCOTT, Derek. "Spreading our Culture Abroad.” The Sunday Guardian. 8 November 1964.

Warnes, Andrew. "Talking Recipes: What Mrs Fisher Knows and the African-American Cookbook Tradition." The Recipe Reader: Narratives, Contexts, Traditions. Ed. Janet Floyd and Laurel Forster. Burlington: Ashgate, 2003. 52-71.

WINER, Lise. Dictionary of the English/Creole of Trinidad and Tobago: On Historical Principles. Kingston: McGill-Queen's UP, 2008. 